\title{
A COMMON LAW JUDGE'S VIEW OF THE APPROPRIATE USE OF ECONOMICS IN COMMON LAW ADJUDICATION
}

\author{
WILlis P. Whichard*
}

I

INTRODUCTION

A discussion of the appropriate use of economics in common law adjudication evokes commentary on the common law itself. Indeed, common law adjudication is a topic to which the giants of legal history have spoken: Justice Holmes, in his essays on the common law; ${ }^{1}$ Justice Cardozo, in The Nature of the Judicial Process ${ }^{2}$ and The Growth of the Law ; Professor Frank, in Law and the Modern Mind; ${ }^{4}$ and Professor Llewellyn, in The Common Law Tradition. ${ }^{5}$ Their observations about the sources of judicial decisionmaking provide a useful introduction to the topic of law and economics.

Holmes' familiar statement is expressed with a lyrical richness in The Common Law:

The life of the law has not been logic: it has been experience. The felt necessities of the time, the prevalent moral and political theories, intuitions of public policy, avowed or unconscious, even the prejudices which judges share with their fellow-men, have had a good deal more to do than the syllogism in determining the rules by which men should be governed. The law embodies the story of a nation's development through many centuries, and it cannot be dealt with as if it contained only the axioms and corollaries of a book of mathematics. 6

While Holmes does not explicitly refer to economics in this passage, experience includes economic experience and public policy includes economic policy. Prejudices include economic prejudices, and a nation's development includes its economic development.

Cardozo reflects on the possibilities and limitations of the creative element in the judicial process:

We are not to bow down before our metaphysical conception or our historic datum, and shut our eyes to living needs, and yet we are not to find a living need in every gust of fancy that would blow to earth the patterns of history and reason. . . Even if it be

Copyright $(\mathcal{C} 1988$ by Law and Contemporary Problems

* Associate Justice, Supreme Court of North Carolina. The author acknowledges with appreciation the assistance of Tracy Kenyon Lischer, his law clerk in 1984-85, in the early research for this article.

1. O. Holmes, The Common Law (1881).

2. B. Cardozo, The Nature of the Judicial Process (1921).

3. B. Cardozo, The Growth of the Law (1924).

4. J. Frank, Law and the Modern Mind (1936).

5. K. Llewellyn, The Common law Tradition: Deciding Appeals (1960).

6. J. Marke, The Holmes Reader 28 (2d ed. 1964). 
true that social welfare is the final test, certainty and order are themselves constituents of the welfare which it is our business to discover. ${ }^{7}$

Again, while the passage does not refer explicitly to the discipline of economics, the phrase "living needs" implicitly encompasses economic needs, and "social welfare" often is economically based.

Further still, Frank expresses paradigmatic realism regarding the judicial process in Law and the Modern Mind:

The present trend of the law is . . away from static security-the preservation of old established rights [including economic rights]-and towards dynamic security [including economic security]-the protection of men engaged in new enterprises [including economic enterprises].

Judges ... do make and change law. ... Why do the courts customarily deny that they have any law-making power and describe new law which they create to deal with essentially contemporary events [including economic events], as mere explanations or interpretations of law which already exists and has existed from time immemorial? Why this obstinate denial of the juristic realities? ${ }^{8}$

Moreover, Llewellyn comments on "The Law of Leeways"9 in the following way:

[T]he greater the felt need [-including economic need-], because of felt sense, the wider is the leeway correctly and properly available in reshaping an authority or the authorities. What is both proper and to be expected in an extreme case would become abuse and judicial usurpation if made daily practice in the mine-run of cases. All courts worthy of their office feel this in their bones, as being inherent in our system of precedent. They show the feeling in their work. Where differences appear is where they should apear: in divergent sizings up of what is sense [-including economic sense], and of how great the need may be in any situation [-including the economic need]. ${ }^{10}$

It is the "felt need" of a current school of jurisprudential thought to proceed beyond these venerable articulations of the common law generally to an analysis of lawmaking which is explicitly economic. It is the purpose of this article to examine the utility of economic analysis in lawmaking from the perspective of the author's personal experience as a judge.

\section{II}

\section{An Overview of the Law and Economics Debate}

It has been suggested that the recent substantive history of the common law represents a movement from paternalism, organicism, or communitarianism $^{11}$ to the late nineteenth-century glorification of the common law "as the legal expression of political and economic individualism."12 The common law has been criticized for its "extreme particularism and individualism," and for its "anti-regulatory premises." 13 In challenging its purported neutrality, legal realists have "demonstrated the

7. B. Cardozo, supra note 3, at 76, 79 (citing B. Cardozo, supra note 2, at 67).

8. J. FRANK, supra note 4 , at 10,33 .

9. The descriptive phrase is from K. Llewellyn, supra note 5, at 220.

10. Llewellyn, Remarks on the Theory of Appellate Decision and the Rules on Canons About How Statutes Are to be Construed, 3 VAND. L. REv. 395, 398 (1950).

11. Horwitz, The Changing Common Law, 9 Dalmousie L.J. 55, 61 (1984).

12. Id. at 59 .

13. Id. at 61 . 
discretionary and political character of common law reasoning." 14 Whether critiquing the theory of precedent, or the nature of legal deduction and analogy, legal scholars have complained that in attempting to do justice in the individual case, common law judges have failed to create "sound rules to govern the behavior of the world at large." 15 The general public believes that justice in the individual case is attained too slowly and at too great a cost.

While in the nineteenth century judge-made common law was thought of as "distinctively state law," 16 there are now entire areas of the federal law which Judge Henry Friendly identifies as "general common law." 17 In the twentieth century, the cultural and political authority of the common law has declined with the rise of the "bureaucratic, regulatory, corporate, welfare state." 18 Horwitz notes the consequent decline in the influence and prestige of state-level common law judges. He states,

Today it seems hard to imagine that the great state common law judges of the 19th century, like Shaw and Cooley, were almost as well known among their contemporaries as the constitutional giants, such as Marshall and Story. By contrast, from the time that Benjamin Cardozo of the New York Court of Appeals ascended the United States Supreme Court bench just over fifty years ago, only one common law judge, Roger Traynor of California, has miraculously transcended the obscurity to which destiny has consigned these oracles of the common law in the twentieth century. Law students in the United States can recite the names and opinions of many lower federal judges; rarely can they do the same for state common law judges. ${ }^{19}$

Thus, law students often know of Richard Posner, Frank Easterbrook, Ruth Bader Ginsburg, and Patrick Higgenbotham. Rarely, however, can they name state-level counterparts to these luminaries. When Posner challenges the assumption that an indigent criminal defendant should have court-appointed counsel, reasoning that the defendant instead should test the merits of his case in the legal marketplace by trying to interest a lawyer in taking the case for a contingent fee, the dissent attains notoriety. ${ }^{20}$ Few opinions of state court judges attract such attention.

Yet, when federal judges are labelled "economists on the bench," their ideas are subjected to harsher criticism than has generally been levelled against traditional common law. Efficiency analysis has been described as "an elegant theory but of little practical relevance." 21 Critics charge that a strong "conservative" bias taints results, that proponents fail to recognize that personal interactions cannot be analyzed with the methods used in investigating impersonal market transactions, and that obsession with

14. Id. at 62 .

15. See Tribe, Constitutional Calculus: Equal Justice or Economic Efficiency?, 98 Harv. L. Rev. 592, 593 (1985) (citing Easterbrook, The Supreme Court, 1983 Term-Foreword: The Court and the Economic System, 98 Harv. L. Rev. 4, 11-12 (1984)).

16. Horwitz, supra note 11 , at 58 .

17. Id. at 65 (citing Friendly, In Praise of Erie-And of the New Federal Common Law, 39 N.Y.U. L. Rev. 383 (1964)).

18. Id. at 59 .

19. Id. at 56 .

20. See Caplan, Does Good Economics Make Good Law?, Cal. Law., May 1985, at 29.

21. Barreto, Husted \& Witte, The New Law and Economics: Present and Future, 1984 Am. B. Found. RES. J. 253, 258. 
efficiency denigrates the concept of justice and equity. ${ }^{22}$ Derek Bok observes that economics most assuredly can illuminate the law, ${ }^{23}$ but Laurence Tribe raises several questions. For example, does the law and economics school of analysis address the crucial question of what counts as a cost or a benefit?24 Does it obscure complex choices by suppressing their controversial nature in supposedly neutral techniques? Does "the exaltation of possessive individualism, 'efficient' resource allocation, and maximum productivity . . . [ignore] distributive justice, procedural fairness, and the . . values associated with personal rights and public goods[?]" 25

The Harvard Law Review exchange between Professor Tribe ${ }^{26}$ and thenProfessor Easterbrook ${ }^{27}$ made these criticisms well-known. In view of these criticisms, of the relegation of the common law to "a more modest role . . in the regulatory state," 28 and of the claims of "[t]heorists of . . . both the Right and Left" that law and economics adherents have abandoned their legal morals, ${ }^{29}$ my topic presents itself in a peculiarly defensive posture. This posture is enhanced by the fact that state appellate judges generally render decisions in "areas of the law where, until recently, economic theory has been considered irrelevant. . . ."30

\section{III}

An Analysis of Law and Economics Based upon Personal Experience as a State Appellate Judge

I thus have chosen to examine the relevance and proper use of economic theory in common law adjudication by considering, briefly, select "hard cases" that I have had to decide. "Hard cases," as defined by Ronald Dworkin, are those in which the result is not clearly dictated by statute or precedent. $^{31}$ In considering these cases I have asked several questions. Did I use economic reasoning to reach a decision? Regardless of whether I used economic reasoning, was the result economically efficient? If economic analysis did not illuminate my decision, did its absence "cost" the parties or society, or sully the law? Finally, should I have aimed for wealth maximization and economic efficiency?

22. Id.

23. Caplan, supra note 20 , at 31 .

24. Tribe, supra note 15 , at 595 .

25. Id. at 597.

26. Tribe, supra note 15 .

27. Easterbrook, supra note 15.

28. Horwitz, supra note 11 , at 65

29. Caplan, supra note 20 , at 30 .

30. Id. at 29.

31. Dworkin, Hard Cases, 88 Harv. L. Rev. 1057, 1058 (1975). 


\section{A. The Use of Economic Analysis in Constitutional Law}

The first case, State $v$. Hunt, ${ }^{32}$ presents an issue of state constitutional law ${ }^{33}$ and also implicates principles of state evidence law. The defendant appealed from a judgment entered upon a conviction of second degree murder in the shooting death of his wife. Prior to trial the defendant had been continually silent about the events surrounding the incident. At trial, however, he testified that he was outside feeding his dogs when the fatal shot was fired, and that the decedent's son, with whom she had just argued, was the culprit. The State was allowed, over objection, to question the defendant about his failure to offer his version of the events to the police officers, or to anyone else, prior to trial. There was no evidence that the defendant had made any pretrial statement or that he had received the Miranda warnings. ${ }^{34}$

The case raised the issue, squarely for the first time in North Carolina, whether a defendant who testifies to an alibi at trial may, absent evidence of Miranda warnings, be impeached by evidence of his pretrial silence. The majority held that absent evidence of Miranda warnings, impeachment by prior silence is permissible if it would have been "natural" for the defendant to have offered his alibi prior to trial. I dissented, ${ }^{35}$ believing such evidence should be inadmissible as violative of the privilege against self-incrimination provided by the state constitution ${ }^{36}$ and as irrelevant for impeachment purposes under general principles of state evidence law. The North Carolina Supreme Court, too, apparently found this a "hard case," for it affirmed the majority, without precedential value, by a tie vote. ${ }^{37}$

While economic analysis can explicate the law, traditional common law judging is biased on the side of mainstream legal theory, the technical foundation of which is the analysis of language. ${ }^{38}$ My dissent in Hunt is based on traditional legal scholarship rather than economic modeling. ${ }^{39}$ It proceeds inductively by examining the language of judges in order to extract principles from particular decisions, rather than deductively by carrying prefabricated hypotheses to the data. ${ }^{40}$ It does not use technical language or invoke the key economic concepts of maximization, equilibrium, or efficiency. ${ }^{41}$ Instead, my dissent rests on such traditional legal concepts as justice, right, and fairness. ${ }^{\mathbf{4 2}}$ It concludes with language traditionally invoked by judges when they

32. 72 N.C. App. 59, 323 S.E.2d 490 (1984).

33. The United States Supreme Court had resolved the issue under the federal Constitution adversely to the defendant. Jenkins v. Anderson, 447 U.S. 231 (1980).

34. 72 N.C. App. at 62,323 S.E. $2 d$ at 492.

35. Id. at 69-80, 323 S.E.2d at 495 .

36. N.C. Const, art. I, \$ 23.

37. State v. Hunt, 313 N.C. 593,330 S.E.2d 205 (1985). The author of the majority opinion in the court of appeals was then on the supreme court and did not sit.

38. Cooter, Law and the Imperialism of Economics: An Introduction to the Economic Analysis of Law and a Review of the Major Books, 29 UCLA L. REV. 1260, 1260 (1982).

39. See id. at 1265 for an explication of the contrasts between economic modeling and traditional legal scholarship.

40. Id.

41. Id.

42. Id. 
undertake to vindicate a fundamental right or to preserve human dignity. To admit evidence of pretrial silence, it states,

allows the State to convert exercise of the privilege against self-incrimination into a sword that pierces the credibility of a defendant who also exercises the right to present a defense at trial through his or her own testimony. The privilege against selfincrimination and the right to present a defense through one's own testimony were never intended to be mutually exclusive in their exercise; to make them so, as the majority opinion here in effect does, places a gloss on the one or the other that tends to negate it. ${ }^{43}$

Use of a more technocratic jurisprudence would not have enhanced the quality of adjudication in Hunt. According to critic and advocate alike, economists on the bench are less interested in doing justice in the case at hand than in creating sound rules to govern the course of future events. ${ }^{44}$ Easterbrook posits that focusing on the equities in the individual case "almost invariably" leads to rules that tend to impoverish people generally. ${ }^{45}$ However, unlike antitrust, securities regulation, employment law, and contracts, where lawyers and judges have long used economic analysis to resolve complex financial and other policy issues, the application of economic analysis to constitutional law generally has been distrusted by all but the staunchest advocates of law and economics. A case such as Hunt, which concerns the right against self-incrimination, demonstrates that justice in the individual case may be a more important goal than sound rules to govern the course of future events. Moreover, justice in the individual case usually results in a sound rule for the future. Economic factors are not the sole grounds for sound rules to govern the course of future events. Tribe's dictum that " $[t]$ he Constitution cannot be cabined in any calculus of costs and benefits" 46 and Justice Stewart's apothegm that "[p]ersonal liberties are not rooted in the law of averages" 47 probably have more adherents than Posner or Easterbrook. As stated by Justice White:

$[T]$ he Constitution recognizes higher values than speed and efficiency. Indeed, one might fairly say of the Bill of Rights in general, and the Due Process clause in particular, that they were designed to protect the fragile values of a vulnerable citizenry from the overbearing concern for efficiency and efficacy that may characterize praise-worthy government officials no less, and perhaps more, than mediocre ones. ${ }^{48}$

\section{B. The Use of Economic Analysis in Family Law}

Family law is another area in which the application of economic theory has generated controversy. ${ }^{49}$ Again, I find among my own opinions a case in

43. 72 N.C. App. at 80,323 S.E.2d at 502 .

44. Tribe, supra note 15, at 593; see Easterbrook, supra note 15, at 5-6.

45. Easterbrook, supra note 15, at 10-11.

46. Tribe, supra note 15 , at 592 ("[C]onstitutional decisions . . must be made as fundamental choices of principle, not as instrumental calculations of social utility." Id. at 621 .).

47. Faretta v. California, 422 U.S. 806, 834 (1975).

48. Stanley v. Illinois, 405 U.S. 645,656 (1972).

49. See Caplan, supra note 20, at 29 (Family law is an area in which "until recently, economic theory has been considered irrelevant."). 
which economic theory seemed irrelevant. In In re Alleghany County v. Reber, 50 respondent-mother's parental rights were terminated on the ground that she had allowed a substantial risk of injury to be created for her three-month-old child by leaving it alone with its father for approximately ten minutes while she went next door to make a phone call.51 When respondent returned she found the child barely breathing. The child was diagnosed as suffering from brain hemorrhage due to trauma. The examining physician believed the injury was due to child abuse such as violent shaking. ${ }^{52}$ Respondent had seen the father handle the child roughly, the father had been abusive toward respondent, and the couple had lost another child who died at the age of two and one-half months of unexplained causes. No charges were filed in the death of the previous child. The father's conviction for child abuse for the injury to this child was reversed for lack of sufficient evidence that the father caused the injury or that it occurred during the ten-minute period in question.

The appellate court had to determine whether the Department of Social Services had shown by clear, cogent, and convincing evidence that abuse or the probability of its repetition existed at the time of the termination proceeding and, if so, whether termination was in the child's best interest. On its facts and the law, this was a "hard case." I concluded, over a dissent, that the evidence established at most a ten-minute lapse of judgment and did not constitute clear, cogent, and convincing evidence that: (1) respondent was unfit to care for the child; (2) there was a probability of repetition of abuse; or (3) termination was in the child's best interest. The North Carolina Supreme Court affirmed in a per curiam opinion. ${ }^{53}$

Child abuse adjudication is particularly unsuited to the application of economic jargon to the competing interests involved. Posner, reflecting Bentham, ${ }^{54}$ states that "the goal of the law is to maximize the welfare or utility of all human beings. . . "55 Parents, however, "cannot be assumed always to . . . desire to maximize their children's utility." 56 Because the child cannot negotiate a long range contract protecting its interest, and because parents have no property rights in their children's lifetime earnings, parents tend to "underinvest" in their children's care and education. 57 "The law," according to Posner, "deals with the problem of underinvestment in children . . by punishing child abuse" and depriving parents of custody or parental rights. ${ }^{58}$ The remedy is inadequate, however, because foster parents also have no property rights in the child's lifetime earnings and thus, like natural parents,

\footnotetext{
50. 75 N.C. App. 467, 331 S.E.2d 256 (1985).

51. Id. at 468,331 S.E.2d at 257.

52. Id. at $468-69,331$ S.E.2d at 257.

53. 315 N.C. 382,337 S.E.2d 851 (1986).

54. See D. Lloyd, Introduction to Jurisprudence 171-73, 199-202 (1979).

55. R. Posner, Economic Analysis of Law 111 (2d ed. 1977).

56. Id.

57. Id.

58. Id. at 112. Robert Cooter perhaps had in mind Posner's allusion to child abuse as a form of underinvestment in children when he stated that Posner's "style is to press forward with economic concepts even at the risk of sounding outrageous." Cooter, supra note 38, at 1267.
} 
"have no incentive to make the investment that will maximize those earnings."59 Posner suggests legalizing baby sales as "an efficient but humane solution to the glut of unwanted children." 60 "[W]illingness to pay is a generally reliable, although not infallible, index of value," he states, "and the parents who value the child the most are likely to give it the most care." 61 Posner admits that the market solution is probably not usable in the case of neglected or abused children because their market price is likely to be negative. ${ }^{62}$

Posner even suggests that " $[t]$ he existence of a market in babies would also increase the natural mother's incentive to produce a healthy baby-and perhaps even make her more selective in her choice of the men with whom she had sexual relations."63 His suggestions evoke memories of Jonathan Swift's A Modest Proposal for Preventing the Children of Poor People in Ireland from Being a Burden to iheir Parents or Country, and for Making Them Beneficial to the Public. ${ }^{64}$ Swift satirically proposed as a "fair, cheap, and easy method of making these children sound, useful members of the commonwealth" selling them to "persons of quality and fortune through the kingdom" as a tasty delicacy. ${ }^{65}$ Posner's suggestion seems more consonant with Swift's reference to mothers as "breeders" whose economic interests will be served by producing plump yearlings for the aristocrat's table $e^{66}$ than with the realities of unplanned and unwanted pregnancies. Posner's proposal does not account for the fact that the wealthy, who have less economic incentive to sell their offspring at a market price, also neglect, abuse, and abort their children.

Would the use of a more technocratic jurisprudence have enhanced the quality of this adjudication? Economic analysis offers marginal assistance. My result is efficient: "An efficient rule maximizes social wealth by minimizing costs to society." 67 If the respondent wants her child and is capable of caring for her, the emotional benefits to parent and child are great. Moreover, the financial cost to society is minimized by avoidance of the monthly expense of foster care services for a disabled child.

Minimization of societal costs was not the ratio decidendi, however. The statutory requirement to show unfitness and the probability of repetition of abuse is "clear, cogent, and convincing evidence."68 This standard was intended to insure justice, not efficiency. Economic analysis would neither have changed the result nor improved the reasoning in the application of the

59. R. Posner, supra note 55, at 112.

60. Id. at 116 .

61. Id. at 114 .

62. Id. at 116.

63. Id. at 114 n.5.

64. The Oxford Anthology of English Literature 1767 (F. Kermode \& J. Hollander eds. 1973).

65. Id. at 1767-69.

66. Id. at 1771 .

67. Comment, The Inefficient Common Law, 92 YaLE L.J. 862, 873 (1983).

68. N.C. Gen. Stat. $\$ 7$ A-289.30(e) (1986); see, e.g., Alleghany County v. Reber, 75 N.C. App. 467, 470, 331 S.E.2d 256, 258 (1985). 
statutory standard to the facts of the case. Calabresi's dictum that "one can [never] trade off efficiency and justice" 69 or "that justice should be a veto on the pursuit of efficiency"70 is pertinent.

\section{The Use of Economic Analysis in Contract Law}

In contrast, the last of my "hard cases" illustrates the utility of economic analysis in common law adjudication. In George $v$. Veach, ${ }^{71}$ plaintiffs purchased from defendants a house constructed by defendant-husband, who was in the business of building and selling houses. The house was equipped with a septic tank system which failed a few months after plaintiffs' occupancy. In plaintiffs' action for breach of implied warranty, the trial court directed a verdict for defendant-builder. The appellate court reversed, based in part on analysis of prior cases that were instructive but not dispositive, and in part on the equities. However, the court also made express use of economic analysis, quoting Posner without apology. The opinion states:

[B]y virtue of superior knowledge, skill, and experience in the construction of houses, a builder-vendor is generally better positioned than the purchaser to know whether a house is suitable for habitation. He also is better positioned to evaluate and guard against the financial risk posed by a defective septic system, and to absorb and spread across the market of home purchasers the loss therefrom. In terms of risk distribution analysis, he is the preferred or "least cost" risk bearer. Finally, he is in a superior position to develop or utilize technology to prevent such defects; and as [Posner] has noted, "the major pockets of strict liability in the law" derive from "cases where the potential victims ... are not in a good position to make adjustments that might in the long run reduce or eliminate the risk."72

Thus, the analytic tools of modern economics can usefully supplement traditional legal research methods, ${ }^{73}$ and "modern economics can be used to illuminate a number of legal problems."74

\section{IV}

\section{Conclusion}

Bok correctly avers that economics can illuminate the law, ${ }^{75}$ and few common law judges would dispute Calabresi's assertion that "if lawyereconomists do not make the mistake of claiming too much for what they are doing, and if they are willing to work at defining and analyzing pretty good instruments leading toward the just society, philosophers ought not to be

69. Calabresi, About Law and Economics: A Letter to Ronald Dworkin, 8 Horstra L. Rev. 553, 557 (1980).

70. Dworkin, Why Efficiency: A Response to Professors Calabresi and Posner, 8 Horstra L. REv. 563, 563 (1980).

71. 67 N.C. App. 674, 313 S.E.2d 920 (1984).

72. Id. at 680, 313 S.E.2d at 923-24 (citing R. Posner, supra note 55, at 140-41).

73. Barreto, Husted \& Witte, supra note 21, at 264.

74. Rowley, Trials on Trial (Book Review), 4 INT'L Rev. L. \& Econ. 89, 89 (1984).

75. Caplan, supra note 20, at 31 (quoting Bok). 
troubled."76 "[T]he appellate firemen . . must respond to all calls," 77 and they should include the tools of modern economic analysis in their firefighting equipment.

The usual case decided by state appellate courts, however, does not involve sophisticated economic analysis. Concerns of stability, continuity, justice, and fairness generally outrank those of wealth maximization and efficiency. While at times it is necessary or appropriate to force the common law into a purely economic mold, this method of adjudication would constitute "abuse and judicial usurpation if made daily practice in the minerun of cases." 78 In Cardozo's words quoted at the outset, "we are not to find a living need [-including an economic need-] in every gust of fancy that would blow to earth the patterns of history and reason." 79

In the late nineteenth century, Justice Holmes prophesied that "the man of the future [would be] the man of statistics and the master of economics." 80 Ten years later, the Brandeis brief in Muller $v$. Oregon ${ }^{81}$ validated this prophecy by initiating the use of social science materials in American courts. ${ }^{82}$ Still later, Cardozo perhaps presaged the "utility" emphasis of law and economics when he wrote:

Some of the errors of courts have their origin in imperfect knowledge of the economic and social consequences of a decision, or of the economic and social needs to which a decision will respond.

Sooner or later, if the demands of social utility are sufficiently urgent, if the operation of an existing rule is sufficiently productive of hardship or inconvenience, utility will tend to triumph. . . . Jurisprudence has never been able in the long run to resist successfully a social or economic need that was strong and just. ${ }^{83}$

Cardozo also wrote that "[n]ot logic alone, but logic supplemented by the social sciences becomes the instrument of advance." 84 Since economics is but one of the social sciences, Cardozo saw it as but one of the needed supplements. "There are times," he wrote, "when precedents seem to lead to harsh or bizarre conclusions, at war with social needs. The law assumes the aspect of a scholastic exercise, divorced from the realities of life. In such junctures, judges would do well to keep before them as a living faith that a choice of methods is theirs in the shaping of their judgments." 85 Ideally, in exercising that "choice of methods," modern common law judges, as "appellate firemen," should be equipped with a working knowledge of all the social sciences, not just economics.

76. Calabresi, supra note 69 , at 561 .

77. Reynolds v. Allstate Ins. Co., 629 F.2d 1111, 1112 (5th Cir. 1980), modified on other grounds, 633 F.2d 1208 (1981).

78. Llewellyn, supra note 10 , at 398 . See also supra text accompanying note 10.

79. B. Cardozo, supra note 3 , at 76 (citing B. Cardozo, supra note 2, at 67).

80. J. Marke, supra note 6, at 28 (citing O. Holmes, The Path of the Law, Collected Legal PAPERS 167, 186, 187 (1920)).

81. 208 U.S. 412,419 n.1 (1908).

82. J. Monahan \& L. Walker, Social Science in Law 8-9 (1985).

83. B. Cardozo, supra note 3 , at 116-18.

84. Id. at 73 .

85. Id. at 65 . 
These judges also should heed Sir Walter Scott's admonition that "[a] lawyer without history or literature is a mechanic, a mere working mason; if he possesses some knowledge of these, he may venture to call himself an architect." 86 The proper model thus is not merely Holmes' "man of statistics and . . . master of economics," 87 but Matthew Arnold's conception of Sophocles as one who "saw life steadily and saw it whole." 88

86. W. Scott \& G. Mannering, Scott's Waverly Novels 251 (Boston ed. 1829).

87. See supra note 80 and accompanying text.

88. M. Arnold, To A Friend, in The Strayed Reveller and Other Poems (1849). 
